\title{
Diversity and potential contribution of wild edible plants to sustainable food security in North Wollo, Ethiopia
}

\author{
AHMED HASSEN \\ Department of Biology, Faculty of Natural and Computational Sciences, Woldia University. Weldiya, Ethiopia. \\ Tel: +251-914070472, "email: ah4674763@gmail.com
}

Manuscript received: 26 March 2021. Revision accepted: 30 May 2021.

\begin{abstract}
Hassen A. 2021. Diversity and potential contribution of wild edible plants to sustainable food security in North Wollo, Ethiopia. Biodiversitas 22: 2501-2510. Rural communities in different parts of the world use WEPs as supplementary food to increase dietary diversity. The findings of this study showed that $40.7 \%$ of the participants were food insecure in the study area. They are significantly dependent on WEPs when sudden drought exists. There were no significant studies conducted about ethnobotany in the study area. Therefore, this study was the first attempt to survey the perception of local people towards the potential resources of WEPs for sustainable food security, and conservation and management trends in North Wollo. Data was collected using semi-structured interviews (135 participants), tour-guided field observation, and focus group discussion (45 participants) to get relevant and adequate data. Descriptive statistics, one-way ANOVA, and preference ranking were used to analyze and interpret the quantitative data. A total of 66 locally available WEPs belong to 30 families found in the study area. Respondents' preference revealed that $O$. ficus-indica, Z.spinachrist, $C$. spinarum, $F$. sur, and $U$. sinesis were ranked first, second, third, fourth, and fifth, respectively. Hence, this study will provide relevant information for policy-makers and managers to combat food insecurity in the study area.
\end{abstract}

Keywords: Conservation and management trends, food insecurity, North Wollo, rural community, sustainable, wild edible plants

\section{INTRODUCTION}

Malnutrition and food scarcity are still among the most striking challenges facing humanity (Redzic 2006, Boedecker et al. 2014). Malnutrition continues as the leading public health problem at the early stages of life in the world (Black et al. 2013). According to Bremner (2012), the continental population of Africa (31\%) was food insecure. Similarly, about $10 \%$ of Ethiopians were with chronic food insecurity, having thousands of children with severe and acute malnutrition (CSAE and ICF International 2016). Ethiopia's malnutrition is among the highest and severe in sub-Saharan African (Christiaensen and Alderman 2004). The prevalence of underweight and stunting among rural children was $27 \%$ and $42 \%$ compared with $13 \%$ and $24 \%$ among urban children, respectively (CSAE 2014).

Wild edible plants (WEPs) are an alternative nature gift to sustainable household food security in developing worlds (Pinela et al. 2017). WEPs contributes as a source of micronutrient and curbing food insecurity for rural communities (Yazew 2020). WEPs are the available source of food in the wild habitat (Heywood 2011, Mahapatra and Panda 2012). Over seven thousand edible plants used as sources of food, rituals, spiritual and cultural value since human beings lived in the cave (Petropoulos et al. 2018). WEPs are a crucial source of nutrition and food security for the developing world. Most of these WEPs can supplement essential nutrient requirements (Hunter et al. 2016). Likewise, Ethiopia has a wide range of topography, edaphic factors, rainfall, and a spectrum of habitats that enhanced over 6500 higher flora species (CBD 2009, Lulekal et al. 2011). The country is one of the 34 global hotspot areas (Awas 1997) and the fifth-largest floral country in tropical Africa (Gebretsadik 2016). The flora diversity of Ethiopia is a rich source of wild and semi-wild plants with edible fruits, stems, leaves, tubers, roots, or whole plant parts (Addis et al. 2013, Burju et al. 2013).

Plant species are threatened with great extinction caused by habitat loss, overexploitation of natural vegetation, climate change, pollution, and invasive alien species. Species may become extinct within decades, and the current rate of global species extinction is higher than the average over the last 10 million years (IPBES 2019). The loss of plant genetic diversity is threatened some lifesaving plants (Uprety et al. 2016). The study districts are among the food insecure areas in Ethiopia (Amarew 2009; Hailu 2013). Many rural communities of Ethiopians, especially children, and women rely on WEPs to get nutrients (Balemie and Kebebew 2006). Despite the current increase of evidence bases quantifying WEPs and threats to them, studies remain limited and uncertain about the local people's perception, conservation, and management trends for sustainability in the future. A better sympathetic about local WEPs are required to enhance agricultural development, natural resource management, and food security, and increase their positive impact on the community. This study was the first attempt to survey the perception of local people on WEPs' potential contribution to sustainable food security, and enhance conservation and management practices in North Wollo, Ethiopia. 


\section{MATERIALS AND METHODS}

\section{Description of the study area}

The study is located in Northeastern Ethiopia lying within $11^{\circ} 50^{\prime} \mathrm{N} 39^{\circ} 15^{\prime} \mathrm{E}$ and $11.833^{\circ} \mathrm{N} 39.250^{\circ} \mathrm{E}$. The study was conducted $521 \mathrm{~km}$ far from Addis Ababa, and $380 \mathrm{~km}$ from the regional capital, Bahirdar. The area is characterized by numerous beautiful irregular topography, mountain chains, and peaks, flatlands, and gorges. An altitude ranges from 980 to 4237 meters above sea level (Figure 1, GIS Satellite map). It has a bimodal rainfall pattern that exists with irregular distribution from late March to early October. The mean annual rainfall and a temperature range from $500-1300 \mathrm{~mm}$ and $10-27^{\circ} \mathrm{C}$, respectively. The study area has a total population of $1,763,245$ and covers a total area of $1,234,547.23$ hectares. The rural population of the district accounts for $88.9 \%$ of the total (NWEDPS 2019).

\section{Data collection instruments}

Ethnobotanical data were collected between February, 05 and December 25, 2020. The study allows diverse evidence from tour-guided field observations, focus group discussions, and semi-structured interviews to obtain indigenous lore of the local community on WEPs. Consent of letter was taken from Woldia University research coordinating office and the interview process and focus discussion session were based on the international codes of ethics and protocol given by Sales and Folkman (2000), and ISE (2006).

The study was conducted with two successive steps. First, tour-guided field survey was conducted to have a basic understanding of the local WEPs' resources and management trends. Next, the researcher assessed the perception of 135 households using interviews (45 participants in each agroclimatic zones), and focus group discussions with 135 participants (15 participants from each agroclimatic zones). A semi-structured interview was prepared that likely affect the perception of local people about WEPs contribution to sustainable food security and conservation and management trends in the study area. Amharic version of semi-structured interviews and focus group discussions were used when collecting data (Appendix 1). Most of the information was gathered technically by speaking to participants (who can't read and write). A checklist was used as a memory guide to facilitate the focus group discussions to maximize and compare the source of information with interview sessions and reject contradictory information.

\section{Species identification}

Preliminary identification for 66 WEPs was in close collaboration with Botany stream lecturers and researchers at Woldia University. Further, identification of species (local name) was conducted by key informants. All specimens were collected, numbered, pressed, dried, and deposited at Woldia University. Scientific names, vernacular names, families, habits, and parts used for consumption are available within the manuscript.

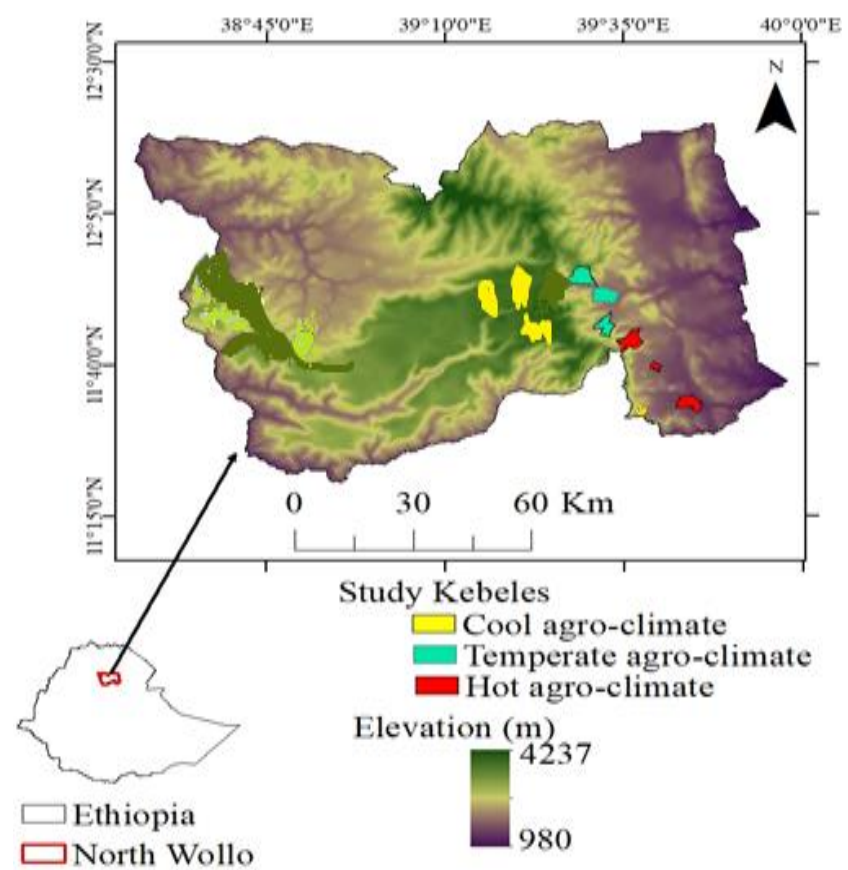

Figure 1. Map of North Wollo with three agroclimatic zones. Kebeles" is an equivalent local name to villages

\section{Data analysis}

A descriptive statistical method was employed to analyze local people's perception of WEPs, conservation strategies, and management trends. Data collected from the household surveys were converted for statistical analysis using IBM SPSS statistics (Version 23). Similarly, preference ranking was conducted to analyze the most popular WEPs based on their contribution to combat malnutrition and food scarcity in the study area as was described by Mengistu and Hager (2008), and Berihun and Molla (2017).

\section{RESULTS AND DISCUSSIONS}

\section{Wild edible plants diversity}

Data collected from tour-guided field observation found that 66 locally available species in the study area. The highest number of species (11) recorded in the Moraceae family followed by Rhamnaceae (5). Tiliaceae, Cucurbitaceae, and Amaranthaceae are represented with four species each. Regarding the habit of their diversity, 28 plant species $(43.08 \%)$ were trees followed by 17 shrub species $(26.15 \%)$ and 16 herbs species $(24.62 \%)$. Dominant wild edible plant parts consumed were from fruits $(66.15 \%)$, followed by leaves $(21.54 \%)$. This indicates that the local vegetation had considerable diversity of WEPs that contribute to the dietary diversity of the residents (See Table 1).

\section{Importance value of WEPs}

Preference ranking for the 20 most popular WEPs with twelve participants was assessed with focus group discussions. Participants notified a preference of one WEP over the other and varied from one village to other. The result of the preference ranking showed that $O$. ficusindica, Z.spina-christi, $C$. spinarum, $F$. sur, and $U$. sinesis were ranked $1 \mathrm{st}, 2^{\text {nd }}, 3^{\text {rd }}, 4^{\text {th }}$, and $5^{\text {th }}$, respectively (Table 2 ). 
Table 1. List of common wild edible plants with their mode of consumption in North Wollo, Ethiopia

\begin{tabular}{|c|c|c|c|c|c|}
\hline The botanical name of the plant & Family & $\begin{array}{l}\text { Common } \\
\text { name }\end{array}$ & Ha & $\mathbf{P u}$ & Mode of consumption \\
\hline Allophyllus abyssinicus (Hochst.) Radlk. & Sapindaceae & Imbis & $\mathrm{S}$ & $\mathrm{F}$ & Fruits edible in raw \\
\hline Amaranthus hybridus L. & Amaranthaceae & Aluma & $\mathrm{S}$ & $\mathrm{L}$ & Cooked leaves are edible \\
\hline Amaranthus spinosus L. & Amaranthaceae & Ferenjaluma & $\mathrm{H}$ & $\mathrm{L}$ & Similar to A. hybridus \\
\hline Amaranthus viridis $\mathrm{L}$. & Amaranthaceae & Aluma & $\mathrm{H}$ & $\mathrm{L}$ & Similar to A. hybridus \\
\hline Balanites aegyptiaca (L.) Del. & Balanitaceae & Beddenno & $\mathrm{H}$ & $\mathrm{F}$ & Fruits are edible in raw \\
\hline Berberis lyceum Royle. & Berberidaceae & Gewo & $\mathrm{S}$ & $\mathrm{F}$ & Raw or cooked fruits are edible \\
\hline Boucerosia indica (Wight\& Arn). & Asclepiadaceae & Gumudo & $\mathrm{H}$ & $\mathrm{Ag}$ & Succulent stem with flower is edible \\
\hline Caralluma edulis (Edgew.) & Asclepiadaceae & Gumudo & $\mathrm{H}$ & $\mathrm{L}^{\circ}$ & Similar to $B$. indica \\
\hline Caralluma tuberculata N.E.Br. & Asclepiadaceae & Gumudo & $\mathrm{H}$ & $\mathrm{Ag}$ & Similar to $B$. indica \\
\hline Carissa spinarum L. & Apocynaceae & Agam & $\mathrm{S}$ & $\mathrm{F}$ & Ripen fruits are edible \\
\hline Casimiroa edulus $\mathrm{L}$. & Rutaceae & Kazamora & $\mathrm{T}$ & $\mathrm{F}$ & Its fruits are edible in raw \\
\hline Celosia argentea $\mathrm{L}$. & Amaranthaceae & - & $\mathrm{H}$ & $\mathrm{L}$ & The arial part is edible \\
\hline Coccinia abyssinica (Lam.)Cong. & Cucurbitaceae & Anchote & $\mathrm{C}$ & $\mathrm{Tu}$ & Its tuber is edible \\
\hline Coccinia grandis (L.) Voigt & Cucurbitaceae & Wergbmeda & $\mathrm{C}$ & $\mathrm{F}$ & Fruits are edible in raw \\
\hline Commelina diffusa Burm. f. & Commelinaceae & Sindelit & $\mathrm{H}$ & $\mathrm{L}$ & Raw leaves are edible vegetable \\
\hline Corchorus trilocularis L. & Tiliaceae & Ged mide & $\mathrm{H}$ & $\mathrm{L}$ & Young leaves are edible in raw \\
\hline Cordia africana Lam. & Boraginaceae & Wanza & $\mathrm{T}$ & $\mathrm{F}$ & Fruits are edible in raw \\
\hline Cucumis dipsaceus Ehrenb Ex. & Cucurbitaceae & Yamoramisa & $\mathrm{C}$ & $\mathrm{L}$ & Raw/cooked vegetable is edible \\
\hline Diospyros mespeliformisA. DC. & Ebenaceae & Ayeh & $\mathrm{T}$ & $\mathrm{F}$ & Ripen fruits are edible \\
\hline Dovyalis abyssinica (A.Rich.) Warb & Flacourtiaceae & Kosim & $\mathrm{S}$ & $\mathrm{F}$ & Similar to D. mespeliformis \\
\hline Ficus auriculata (Lour.) & Moraceae & - & $\mathrm{T}$ & $\mathrm{F}$ & Similar to $D$. mespeliformis \\
\hline Ficus capreaefolia Del. & Moraceae & - & $\mathrm{T}$ & $\mathrm{F}$ & Similar to $F$. auriculata \\
\hline Ficus carica $\mathrm{L}$. & Moraceae & Beles & $\mathrm{T}$ & $\mathrm{F}$ & Similar with $F$. auriculata \\
\hline Ficus ingens (Miq.) Miq. & Moraceae & - & $\mathrm{T}$ & $\mathrm{F}$ & Similar to $F$. auriculata \\
\hline Ficus ovata Vahl. & Moraceae & Warka & $\mathrm{T}$ & $\mathrm{F}$ & Similar to $F$. auriculata \\
\hline Ficus palmata Forssk. & Moraceae & Qolla Beles & $\mathrm{T}$ & $\mathrm{F}$ & Similar to $F$. auriculata \\
\hline Ficus sur Forssk. & Moraceae & Shola & $\mathrm{T}$ & $\mathrm{F}$ & Similar to $F$. auriculata \\
\hline Ficus sycomorus L. & Moraceae & Bamba & $\mathrm{T}$ & $\mathrm{F}$ & Similar to $F$. auriculata \\
\hline Grewia bicolor Juss. & Tiliaceae & Somaya & $\mathrm{T}$ & $\mathrm{F}$ & Similar to $F$. auriculata \\
\hline Grewia ferruginea Hochst. ex A. Rich. & Tiliaceae & Lenkwata & $\mathrm{T}$ & $\mathrm{F}$ & Similar to $F$. auriculata \\
\hline Grewia tenax (Forssk.) Fiori. & Tiliaceae & Hoba & $\mathrm{T}$ & $\mathrm{F}$ & Ripen fruits are edible in raw \\
\hline Lantana camara $\mathrm{L}$. & Verbenaceae & Yewof-qolo & $\mathrm{S}$ & $\mathrm{F}$ & Fruits are edible \\
\hline Mimusops kummel Bruce ex A.DC & Sapotaceae & Ishe & $\mathrm{T}$ & $\mathrm{F}$ & Ripen fruits are edible in raw \\
\hline Momordica dioica Roxb.ex Willd & Cucurbitaceae & Wof techj & $\mathrm{C}$ & $\mathrm{F}$ & Fruits are edible in raw \\
\hline Moringa oleifera Lam. & Moringaceae & Shiferaw & $\mathrm{T}$ & $\mathrm{L}$ & Cooked leaves are edible \\
\hline Moringa stenopetala (Bak.f.) Cufod. & Moringaceae & Shiferaw & $\mathrm{T}$ & $\mathrm{L}$ & Similar to M. oleifera \\
\hline Morus alba L. & Moraceae & Nech Enjori & $\mathrm{T}$ & $\mathrm{F}$ & Fruits are edible in raw form \\
\hline Morus nigra $\mathrm{L}$. & Moraceae & Tikur Enjori & $\mathrm{T}$ & $\mathrm{F}$ & Similar to M. alba \\
\hline Nasturtium officinale W.T. Aiton & Brassicaceae & Guguble & $\mathrm{H}$ & $\mathrm{Ag}$ & Mostly cooked or edible in raw \\
\hline Opuntia ficus-indica (L.) Miller & Cactaceae & Bahrqulqual & $\mathrm{S}$ & $\mathrm{F}$ & Ripen fruits are edible \\
\hline Opuntia hyptiacantha F.A.C.Weber & Cactaceae & Bahrqulqual & $\mathrm{S}$ & $\mathrm{F}$ & Similar to $O$. ficus-indica \\
\hline Opuntia streptacantha Lem. & Cactaceae & Bahrqulqual & $\mathrm{S}$ & $\mathrm{F}$ & Similar to $O$. ficus-indica \\
\hline Oxalis stricta $\mathrm{L}$ & Oxalidaceae & Yeberechew & $\mathrm{H}$ & $\mathrm{Ag}$ & Arial shoots are edible in raw \\
\hline Pentarrhinum insipidum E.Mey. & Apocynaceae & Gumud & $\mathrm{H}$ & $\mathrm{Ag}$ & Similar to $B$. indica \\
\hline Physalis peruviana $\mathrm{L}$. & Solanaceae & Nech-awet & $\mathrm{H}$ & $\mathrm{F}$ & Fruits are edible in raw \\
\hline Portulaca oleracea L. & Portulacaceae & - & $\mathrm{H}$ & $\mathrm{L}$ & Raw leaves and shoots edible \\
\hline Portulaca quadrifida $\mathrm{L}$ & Portulacaceae & - & $\mathrm{H}$ & $\mathrm{L}$ & Used as salad/vegetable \\
\hline Rosa abyssinica $\mathrm{L}$. & Rosaceae & Kega & $\mathrm{S}$ & $\mathrm{F}$ & Similar to $C$. spinarum \\
\hline Rubus Fruticosus L. & Moraceae & Enjori & $\mathrm{S}$ & $\mathrm{F}$ & Similar to C. spinarum \\
\hline Rumex abyssinicus Jacq. & Polygonaceae & Mokmoko & S & RS & $\begin{array}{l}\text { The tuber used as a tea and Juvenile } \\
\text { shoot is edible in raw }\end{array}$ \\
\hline Rumex nervosus Vahl. & Polygonaceae & Embacho & $\mathrm{S}$ & & The succulent shoot is edible \\
\hline Sageretia thea (Osbeck) M.C. Johnston. & Rhamnaceae & Kichil agam & $\mathrm{S}$ & $\mathrm{F}$ & Ripen fruits are edible in raw \\
\hline Sclerocarya birrea (A.Rich.) Hochst. & Anacardiaceae & & $\mathrm{T}$ & $\mathrm{F}$ & Ripen fruits are edible in raw \\
\hline Sisymbrium officinale (L) Scop. & Brassicaceae & Senafich & $\mathrm{H}$ & $\mathrm{L}$ & Cooked leaves are edible \\
\hline Solanum nigrum L. & Solanaceae & Tikur-awit & $\mathrm{S}$ & $\mathrm{F}$ & Similar to $P$. peruviana \\
\hline Solanum torvum SW. & Solanaceae & Awit & $\mathrm{S}$ & $\mathrm{F}$ & Similar to $P$. peruviana \\
\hline Syzygium guineense (Willd.) DC & Myrtaceae & Dogma & $\mathrm{T}$ & $\mathrm{F}$ & Similar to C. spinarum \\
\hline Tamarindus indica $\mathrm{L}$. & Fabaceae & Humer & $\mathrm{T}$ & FS & Ripen fruits and seeds are edible \\
\hline Urtica sinesis $\mathrm{L}$. & Urticaceae & Samma & $\mathrm{H}$ & $\mathrm{L}$ & Cooked leaves are edible \\
\hline Vitex doniana Sweet. & Verbenaceae & Plem & $\mathrm{T}$ & $\mathrm{F}$ & Ripen fruits are edible \\
\hline Ximenia americana L. & Olacaceae & Enkoy & $\mathrm{T}$ & $\mathrm{F}$ & Ripen fruits are edible \\
\hline Ximenia caffra Sond. & Olacaceae & - & $\mathrm{T}$ & $\mathrm{F}$ & Fruits are edible in raw form \\
\hline Ziziphus abyssinica Hochst. ex A. Rich & Rhamnaceae & - & $\mathrm{S}$ & $\mathrm{F}$ & Ripen fruits are edible \\
\hline Ziziphus jujuba Mill. & Rhamnaceae & Kurkura & $\mathrm{T}$ & $\mathrm{F}$ & Similar to Z. abyssinica \\
\hline Ziziphus mucronata Wild. & Rhamnaceae & Ado-qurqura & $\mathrm{T}$ & $\mathrm{F}$ & Similar to Z. abyssinica \\
\hline Ziziphus spina-christi (L.) Desf). & Rhamnaceae & Kurkura & $\mathrm{T}$ & $\mathrm{F}$ & Similar to Z. abyssinica \\
\hline
\end{tabular}

Note: Parts used (Pu) Habit (Ha), Tree (T), Leaf (L), fruit and leaf (FL), Leaves and seeds (LS), Fruits and Seeds (FS), Climber (C), Flower (Fr), Stem (St), root and stem (RS), Above ground (Ag), Arial shoot with leaves (As), Tuber (Tu) 
Table 2. Preference ranking for popular WEPs based on taste in north Wollo, Ethiopia

\begin{tabular}{|c|c|c|c|c|c|c|c|c|c|c|c|c|c|c|}
\hline Species/Respondent & R1 & $\mathbf{R 2}$ & $\mathbf{R 3}$ & R4 & R5 & R6 & R7 & $\mathbf{R 8}$ & R9 & R10 & R11 & R12 & Total & Rank \\
\hline A. spinosus & 10 & 6 & 6 & 8 & 9 & 6 & 8 & 8 & 8 & 16 & 6 & 6 & 69 & $13^{\text {th }}$ \\
\hline B. lyceum & 6 & 8 & 8 & 4 & 1 & 1 & 6 & 4 & 5 & 13 & 8 & 1 & 43 & $17^{\text {th }}$ \\
\hline C. spinarum & 17 & 20 & 18 & 20 & 15 & 19 & 15 & 15 & 20 & 15 & 18 & 18 & 159 & $3^{\text {rd }}$ \\
\hline D. abyssinica & 2 & 2 & 3 & 12 & 4 & 7 & 4 & 12 & 1 & 3 & 3 & 3 & 47 & $16^{\text {th }}$ \\
\hline F. sur & 15 & 19 & 12 & 17 & 18 & 13 & 16 & 17 & 19 & 11 & 12 & 9 & 146 & $4^{\text {th }}$ \\
\hline M. alba & 13 & 7 & 15 & 7 & 10 & 2 & 5 & 7 & 10 & 19 & 15 & 8 & 76 & $12^{\text {th }}$ \\
\hline M. nigra & 3 & 1 & 2 & 1 & 2 & 3 & 3 & 1 & 2 & 2 & 2 & 2 & 18 & $20^{\text {th }}$ \\
\hline M. oleifera & 8 & 4 & 7 & 3 & 5 & 11 & 14 & 3 & 14 & 4 & 7 & 13 & 69 & $13^{\text {th }}$ \\
\hline N. officinale & 18 & 10 & 20 & 9 & 12 & 18 & 10 & 9 & 6 & 5 & 20 & 19 & 112 & $8^{\text {th }}$ \\
\hline O. ficus-indica & 20 & 17 & 17 & 19 & 17 & 20 & 18 & 19 & 15 & 20 & 17 & 20 & 162 & $1^{\text {st }}$ \\
\hline P. insipidum & 5 & 3 & 5 & 2 & 6 & 5 & 2 & 2 & 3 & 14 & 5 & 5 & 33 & $19^{\text {th }}$ \\
\hline P. peruviana & 12 & 11 & 11 & 18 & 7 & 12 & 9 & 18 & 16 & 6 & 11 & 12 & 114 & $7^{\text {th }}$ \\
\hline R. abyssinica & 16 & 16 & 19 & 10 & 16 & 15 & 13 & 10 & 13 & 12 & 19 & 16 & 128 & $6^{\text {th }}$ \\
\hline R. nervosus & 9 & 9 & 10 & 11 & 13 & 10 & 11 & 11 & 11 & 1 & 10 & 14 & 95 & $11^{\text {th }}$ \\
\hline Rumex abyssinicus & 1 & 5 & 4 & 8 & 3 & 4 & 7 & 6 & 4 & 7 & 4 & 4 & 42 & $18^{\text {th }}$ \\
\hline S. guineense & 7 & 12 & 14 & 14 & 11 & 9 & 19 & 14 & 7 & 9 & 14 & 10 & 107 & $10^{\text {th }}$ \\
\hline T. indica & 14 & 15 & 9 & 13 & 14 & 8 & 12 & 13 & 12 & 10 & 9 & 15 & 110 & $9^{\text {th }}$ \\
\hline$U$. sinesis & 11 & 14 & 13 & 16 & 20 & 14 & 17 & 16 & 18 & 8 & 13 & 11 & 139 & $5^{\text {th }}$ \\
\hline$X$. americana & 4 & 13 & & 5 & 8 & 16 & 1 & 5 & 9 & 18 & 1 & 7 & 61 & $15^{\text {th }}$ \\
\hline Z. spina-christi & 19 & 18 & 16 & 15 & 19 & 17 & 20 & 20 & 17 & 17 & 16 & 17 & 161 & $2^{\text {nd }}$ \\
\hline
\end{tabular}

Note: Respondent in focus group discussion (R), Points was given in decreasing order (maximum point of 20) is given for the most popular and flavored fruit or vegetable, and 1 is given for the least popular one accordingly)

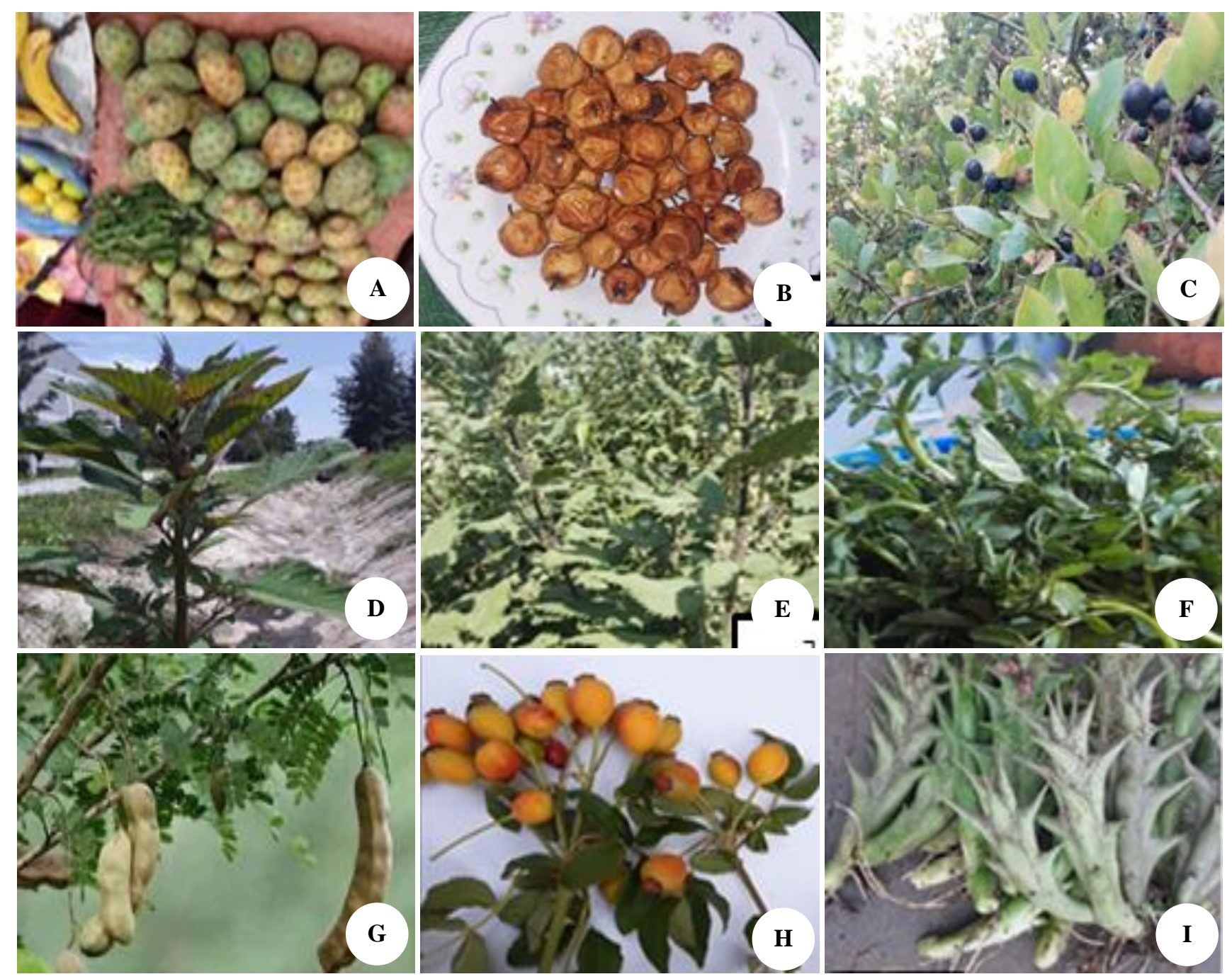

Figure 2. Top popular WEPs in north Wollo showing Opuntia fruits in the market (A), Z. Spina-christi ripen fruits ready for use (B), $C$. spinarum fruits (C), Amaranthus shoot (D), U. sinensis shoot (E), N. Officinale shoots (F), T. indica. fruits (G), R. abyssinica fruits (H), and C.sprengeri succulent stems (I) 
The demographic characteristics of surveyed districts

The results of the surveyed households revealed that there were more male respondents $(64.4 \%)$ compared to females $(35.6 \%)$. The age of the participants was in the range of 18-100years. The majority of the participants practiced Ethiopian Orthodox Christianity (80\%) and $18.5 \%$ of the study population were Muslims. The statistical analysis result revealed that $44.4 \%$ of the respondents illiterate, whereas $55.6 \%$ were literate. The economic activity is primarily depending on a mixed farming system (74.1\%). A few of them were civil servants $(7.4 \%)$, merchants $(5.2 \%)$, private businesses $(3.7 \%)$, and jobless $(5.2 \%)$. Most of the household participants (68.9\%) reported having 1-3 family members. The majority of the respondents $(71.1 \%)$ were familiar with WEPs in their surroundings. Among all interviewed, $40.7 \%$ and $59.3 \%$ found food insecure and food secure, respectively (Table 3).

Table 3. Demographic characteristics of respondents in the surveyed districts in North Wollo, Ethiopia

\begin{tabular}{|c|c|c|c|}
\hline Variables & $\begin{array}{l}\text { Descriptive } \\
\text { alternatives }\end{array}$ & Frequency & $\begin{array}{l}\text { Proportion } \\
(\%)\end{array}$ \\
\hline $\begin{array}{ll}\text { Total } & \text { sample } \\
\text { size }(\mathrm{N}) & \end{array}$ & 135 households & & \\
\hline \multirow[t]{2}{*}{ Sex } & M & 87 & 64.4 \\
\hline & $\mathrm{F}$ & 48 & 35.6 \\
\hline \multirow[t]{9}{*}{ Age } & $18-28$ & 19 & 14.1 \\
\hline & $29-39$ & 30 & 22.2 \\
\hline & $40-50$ & 30 & 22.2 \\
\hline & $51-61$ & 22 & 16.3 \\
\hline & $62-72$ & 18 & 13.3 \\
\hline & $73-83$ & 14 & 10.4 \\
\hline & $84-94$ & 1 & 0.7 \\
\hline & $95-100$ & 1 & 0.7 \\
\hline & Orthodox & 108 & 80 \\
\hline \multirow[t]{2}{*}{ Religion } & Muslim & 25 & 18.5 \\
\hline & Protestant & 2 & 1.5 \\
\hline \multirow[t]{4}{*}{ Education } & No education & 60 & 44.4 \\
\hline & Primary education & 49 & 36.3 \\
\hline & $\begin{array}{l}\text { Secondary } \\
\text { education }\end{array}$ & 22 & 16.3 \\
\hline & Higher education & 4 & 3 \\
\hline \multirow[t]{6}{*}{ Occupation } & Farmer & 100 & 74.1 \\
\hline & Civil servant & 10 & 7.4 \\
\hline & Merchant & 7 & 5.2 \\
\hline & $\begin{array}{l}\text { Both farmer and } \\
\text { merchant }\end{array}$ & 6 & 4.4 \\
\hline & Not working & 7 & 5.2 \\
\hline & Private business & 5 & 3.7 \\
\hline \multirow[t]{4}{*}{ Family size } & 1-3 members & 93 & 68.9 \\
\hline & 4-7 members & 35 & 25.9 \\
\hline & 8-12 members & 5 & 3.7 \\
\hline & Above 12 & 2 & 1.5 \\
\hline \multirow[t]{2}{*}{ Food secure } & Yes & 80 & 59.3 \\
\hline & No & 55 & 40.7 \\
\hline \multirow{3}{*}{$\begin{array}{l}\text { Familiarity } \\
\text { with WEPs }\end{array}$} & Yes & 96 & 71.1 \\
\hline & No & 20 & 14.8 \\
\hline & Little bit & 19 & 14.1 \\
\hline
\end{tabular}

\section{Habit, habitat, and use categories of WEPs}

The habit, habitat, and use categories of WEPs from interview reports are shown in table 4 below. Based on the interviewed respondents, the most common species obtained from shrubland $(41.5 \%)$ followed by forest $(27.4$ $\%)$, agricultural land $(18.5 \%)$, and grassland (12.6\%). In terms of habit, the majority of the WEPs were trees $(43.7 \%)$, followed by shrubs $(38.5 \%)$ and herbs $(17.0 \%)$. The dominant edible parts were fruits $(71.1 \%)$ followed by leaves $(15.6 \%)$ and aerial shoots $(11.1 \%)$. Most of the WEPs eaten in the raw state $(60.0 \%)$, cooked $(28.9 \%)$, processed as an alcoholic drink (7.4\%), and in a roasted form $(3.7 \%)$. Residents perceived using WEPs mainly as household dietary supplements $(28.9 \%)$, firewood consumption (26.7\%), charcoal production (13.3\%), medicine $(10.4 \%)$, and spice in their diet $(6.7 \%)$.

Table 4. WEPs habit, habitat, and use categories of respondents in North Wollo, Ethiopia

\begin{tabular}{|c|c|c|c|}
\hline Variables & $\begin{array}{l}\text { Description } \\
\text { /alternatives }\end{array}$ & Frequency & $\begin{array}{l}\text { Percentage } \\
(\%)\end{array}$ \\
\hline \multirow[t]{4}{*}{ Habitat } & Forest & 37 & 27.4 \\
\hline & Shrubland & 56 & 41.5 \\
\hline & Grassland & 17 & 12.6 \\
\hline & Agricultural land & 25 & 18.5 \\
\hline \multirow[t]{4}{*}{ Habit } & Tree & 59 & 43.7 \\
\hline & Shrub & 52 & 38.5 \\
\hline & Herb & 23 & 17.0 \\
\hline & Climber & 1 & 0.7 \\
\hline \multirow[t]{4}{*}{ Parts used } & Fruit & 96 & 71.1 \\
\hline & Leaves & 21 & 15.6 \\
\hline & Root/Tubers & 3 & 2.2 \\
\hline & Arial shoot & 15 & 11.1 \\
\hline \multirow{4}{*}{$\begin{array}{l}\text { Mode of } \\
\text { consumption }\end{array}$} & Raw state & 81 & 60.0 \\
\hline & Cooked & 39 & 28.9 \\
\hline & Roasted form & 5 & 3.7 \\
\hline & $\begin{array}{l}\text { Processed as } \\
\text { alcohol/Juice }\end{array}$ & 10 & 7.4 \\
\hline \multirow[t]{6}{*}{$\begin{array}{l}\text { The first choice } \\
\text { to use WEPs }\end{array}$} & $\begin{array}{l}\text { Supplementary } \\
\text { food }\end{array}$ & 39 & 28.9 \\
\hline & Medicine & 14 & 10.4 \\
\hline & Spice & 9 & 6.7 \\
\hline & Firewood & 36 & 26.7 \\
\hline & Charcoal & 18 & 13.3 \\
\hline & $\begin{array}{l}\text { Ecological } \\
\text { significance }\end{array}$ & 8 & 5.9 \\
\hline
\end{tabular}

Table 5. Harvesting seasons and an annual yield of WEPs in north Wollo, Ethiopia

\begin{tabular}{|c|c|c|c|}
\hline Variables & $\begin{array}{l}\text { Descriptive } \\
\text { alternatives }\end{array}$ & Frequency & $\begin{array}{l}\text { Percent } \\
(\%)\end{array}$ \\
\hline \multirow[t]{4}{*}{ Harvesting seasons } & Summer & 70 & 51.9 \\
\hline & Winter & 16 & 11.9 \\
\hline & Autumn & 37 & 27.4 \\
\hline & Spring & 11 & 8.1 \\
\hline \multirow{4}{*}{$\begin{array}{l}\text { Annual } \\
\text { approximate yield } \\
\text { of WEPs }\end{array}$} & $1-25 \mathrm{~kg}$ & 25 & 18.5 \\
\hline & $26-50 \mathrm{~kg}$ & 38 & 28.1 \\
\hline & $51-75 \mathrm{~kg}$ & 49 & 36.3 \\
\hline & $76-100 \mathrm{~kg}$ & 23 & 17.0 \\
\hline
\end{tabular}




\section{Seasonal pattern for harvesting, proximate yield, and} market survey of WEPs

According to respondents and repeated market surveys, the cactus fruits were the first popular merchantable wild fruits followed by Z. spina-christi fruits. Table 5 below revealed that summer was the highest harvesting season $(51.9 \%)$ followed by autumn (27.4\%). Among all, spring was reported as the minimum harvesting season $(8.1 \%)$. The highest approximate annual yield range of $51-75 \mathrm{~kg}$ followed by $26-50 \mathrm{~kg}$, and $1-25 \mathrm{~kg}$ (Table 5 ).

\section{Local perceptions, threat, and conservation practices}

The researcher asked respondents about the potential resources and uses of WEPs. Accordingly, most of them replied as WEPs are vital as sources of supplementary diet in their life. The role of collecting and harvesting was mainly by children $(46.3 \%)$, followed by women $(28.4 \%)$, and by all age groups (14.9\%). Men were reported less in collecting fruits and vegetables from wildlife (10.4\%). Traditional cultures and beliefs $(46.7 \%)$ were the leading challenges to domesticate WEPs followed by the erosion of the lore by the young generation $(31.1 \%)$ in the study area. Further, the majority of respondents were not practicing at least key species conservation $(58.5 \%)$. Some of them had in situ $(36.3 \%)$ and ex situ conservation practices (5.2\%) (Table 6).

Socio-demographic characteristics of the respondents revealed the educational level, approximate annual yield, conservation practices, threat, and the challenge domesticate WEPs were significant while others were not (Table 7).

Agro climate condition correlation was significant with an annual yield of WEPs. As indicated in Table 8, the Pearson Correlation coefficient of the agro-ecological zone was statistically significant at the 0.01 level (2-tailed).

Table 6. Challenges to cultivate and domesticate WEPs in north Wollo

\begin{tabular}{|c|c|c|c|}
\hline Variables & Descriptive alternatives & Frequency & Percent \\
\hline \multirow[t]{4}{*}{ Role of collecting } & Children & 63 & 46.7 \\
\hline & Women & 38 & 28.1 \\
\hline & Men & 14 & 10.4 \\
\hline & All & 20 & 14.8 \\
\hline \multirow[t]{7}{*}{ Challenges to domesticate and cultivate WEPs } & Strong traditional believes & 63 & 46.7 \\
\hline & Religious taboos & 3 & 2.2 \\
\hline & Inadequate labor resources & 7 & 5.2 \\
\hline & Erosion by the young generation & 42 & 31.1 \\
\hline & Unpleasant taste & 4 & 3.0 \\
\hline & Time is taken for collection & 6 & 4.4 \\
\hline & Quantity and unsustainable harvest & 10 & 7.4 \\
\hline \multirow[t]{4}{*}{ Threats to WEPs } & Deforestation & 79 & 58.5 \\
\hline & Agricultural expansion & 32 & 23.7 \\
\hline & Overexploitation & 6 & 4.4 \\
\hline & Habitat destruction and loss & 18 & 13.3 \\
\hline \multirow[t]{3}{*}{ Conservation measures taken } & In situ conservation & 49 & 36.3 \\
\hline & Ex-situ conservation & 7 & 5.2 \\
\hline & No conservation taken & 79 & 58.5 \\
\hline
\end{tabular}

Table 7. One way ANOVA description of respondents' attributes in the agro-ecological zone

\begin{tabular}{|c|c|c|c|c|c|c|}
\hline Descriptions & & $\begin{array}{l}\text { Sum of } \\
\text { squares }\end{array}$ & df & $\begin{array}{l}\text { Mean } \\
\text { square }\end{array}$ & $\mathbf{F}$ & Sig. \\
\hline \multirow[t]{2}{*}{ The education level of the respondent } & Between Groups & 7.600 & 2 & 3.800 & 5.990 & $0.003 *$ \\
\hline & Within Groups & 83.733 & 132 & 0.634 & & \\
\hline \multirow[t]{2}{*}{ Occupation status of the respondent } & Between Groups & 7.348 & 2 & 3.674 & 1.903 & 0.153 \\
\hline & Within Groups & 254.800 & 132 & 1.930 & & \\
\hline \multirow[t]{2}{*}{ Clinical malnutrition record before } & Between Groups & 0.726 & 2 & 0.363 & 2.023 & 0.136 \\
\hline & Within Groups & 23.689 & 132 & 0.179 & & \\
\hline \multirow[t]{2}{*}{ Route of consumption } & Between Groups & 2.415 & 2 & 1.207 & 1.588 & 0.208 \\
\hline & Within Groups & 100.356 & 132 & 0.760 & & \\
\hline \multirow[t]{2}{*}{ Seasons when WEPs available most } & Between Groups & 2.237 & 2 & 1.119 & 0.939 & 0.394 \\
\hline & Within Groups & 157.289 & 132 & 1.192 & & \\
\hline \multirow[t]{2}{*}{ The approximate annual yield of WEPs } & Between Groups & 26.770 & 2 & 13.385 & 17.165 & $0.0001 *$ \\
\hline & Within Groups & 102.933 & 132 & 0.780 & & \\
\hline \multirow[t]{2}{*}{ The first choice to use WEPs } & Between Groups & 15.600 & 2 & 7.800 & 1.998 & 0.140 \\
\hline & Within Groups & 515.333 & 132 & 3.904 & & \\
\hline \multirow[t]{2}{*}{ Role of collecting WEPs } & Between Groups & 1.244 & 2 & 0.622 & 0.529 & 0.590 \\
\hline & Within Groups & 155.156 & 132 & 1.175 & & \\
\hline \multirow[t]{2}{*}{ Threat to WEPs } & Between Groups & 6.948 & 2 & 3.474 & 3.278 & $0.041^{*}$ \\
\hline & Within Groups & 139.911 & 132 & 1.060 & & \\
\hline \multirow[t]{2}{*}{ Challenge to WEPs } & Between Groups & 30.178 & 2 & 15.089 & 4.035 & $0.020 *$ \\
\hline & Within Groups & 493.556 & 132 & 3.739 & & \\
\hline \multirow[t]{2}{*}{.Conservation measures taken } & Between Groups & 13.333 & 2 & 6.667 & 8.148 & $0.0001 *$ \\
\hline & Within Groups & 108.000 & 132 & 0.818 & & \\
\hline
\end{tabular}

Note: $* \mathrm{P}$ value is significant at $\mathrm{p}<.05$ level 
Table 8. Agro climate condition correlations with an approximate annual yield of WEP

\begin{tabular}{llll}
\hline & & $\begin{array}{l}\text { The approximate annual } \\
\text { yield of WEPs }\end{array}$ & $\begin{array}{l}\text { Agro climate condition of } \\
\text { the WEPs }\end{array}$ \\
\hline $\begin{array}{lll}\text { Annual approximate yield } \\
\text { of WEPs }\end{array}$ & $\begin{array}{l}\text { Pearson Correlation } \\
\text { Sig. (2-tailed) }\end{array}$ & & $0.414^{* *}$ \\
& Sum of Squares and Cross-products & 129.704 & 0.000 \\
& Covariance & 0.968 & 44.519 \\
& $\mathrm{~N}$ & 135 & 0.332 \\
Agro climate condition of & Pearson Correlation & $0.414^{* *}$ & 135 \\
the WEPs & Sig. (2-tailed) & 0.000 & 1 \\
& Sum of Squares and Cross-products & 44.519 & 88.993 \\
& Covariance & 0.332 & 0.664 \\
& N & 135 & 135 \\
\hline
\end{tabular}

Note: $* *$. Correlation is significant at the 0.01 level (2-tailed)

\section{Discussion}

WEPs are an alternative nature gift to sustainable household food security in developing worlds (Pinela et al. 2017). Therefore, this study has investigated the perception of local household participants on the potential resources of WEPs, conservation, and management trends for sustainable food security. It primarily aimed to enhance the nutritional security of rural households by encouraging the adoption of conservation and management strategies of lifesaving WEPs.

WEPs were surveyed from agricultural fields, grasslands, shrublands, and forests as it was described by Regassa et al. (2014). In the present study, sixty-five WEPs were explored in the local community. This study was incomparable with Addis et al. (2013) and Lulekal et al. (2011) who reported 137 and 137413 WEPs in different parts of Ethiopia. In contrast, it was comparable to Balemie and Kebebew (2006) who reported 66 WEPs in a different part of Ethiopia. Most of the WEPs were trees followed by shrubs (Table 1). It was in agreement with an earlier study by Berihun and Molla (2017) and Fentahun and Hager (2008) in the Amhara region. However, it was in contrast to the reports of Lulekal et al. (2011) and Ashagre et al. (2016) indicated that shrubs were the dominant growth forms followed by trees, herbs, and climbers. Local people preferably consume fruits in the raw state without any further processing (Table 1 and 4). This result was in agreement with Ashagre et al. (2014), and Berihun and Molla (2017), Lulekal et al. (2011). The role of collecting and harvesting WEPs was mainly by children and women, which revealed their positive association with WEPs. It was similar to the report of Tadesse et al. (2004).

The study revealed that respondents were primarily dependent on a mixed farming system (Table 3 ). The findings of this study showed that thousands of citizens were food insecure. This is in agreement with the reports of Amarew (2009) and Hailu (2013). Local people perceived using WEPs for multiple purposes. This was shown with the tour-guided field survey and interview results (Table 1 and Table 4). It was similar with Heywood (2011), and Mahapatra and Panda (2012) who were reported the multiple benefits of WEPs (household dietary supplements, firewood consumption, charcoal production, medicine, spice, ecological significance, etc.). One-way ANOVA socioeconomic characteristics and descriptive results revealed that educational status, approximate annual yield, conservation practices, threat, and the challenge to domesticate WEPs were significant while others were not (Table 7).

Preference ranking was conducted for the most popular WEPs based on their contribution to alleviating malnutrition and food scarcity in the study area. They notified that wild fruits and vegetables are commonly eaten by children, adults, livestock, birds, and wild animals in their environment. Preference ranking revealed that $O$. ficus-indica, Z. spina-christi, C. spinarum, $F$. sur, and $U$. sinensis were prioritized $1^{\text {st }}, 2^{\text {nd }}, 3^{\text {rd }}, 4^{\text {th }}$, and $5^{\text {th }}$ based on their flavor and nutritional value (Table 3, Figure 2). Cactus species and Z. spina-christi fruits were the only marketable fruits in North Wollo (Figure 2). It was in agreement with the studies conducted in Ethiopia by Berihun and Molla (2017). However, Fentahun and Hager (2008) reported that $S$. guineense, $T$. indica, and $C$. Spinarum fruits were marketable in different parts of the Amhara region. Some respondents notified that they use WEPs at times of both food plenty and scarcity. This study revealed that autumn and summer seasons were the highest collections and harvesting periods. Likewise, Assefa and Abebe (2011) have found the same findings in different parts of Ethiopia. Russo et al. (2017) findings were also similar to studies conducted outside Ethiopia. Table 8 revealed the Pearson correlation coefficient of the agroecological zone with the annual yield of WEPs was significant (p-Value, 0.01).

Land degradation is the first ecosystem threat to sustainability and stability (Mulatie et al. 2015). It leads to overexploitation of the remaining natural resources (Meseret 2016) and a massive extinction of important plant species (Barlow et al. 2007, Chazdon 2018). Similarly, the potential resources of WEPs in the study area are threatened with anthropogenic causes(deforestation for firewood, charcoal, construction materials, agricultural land demand, etc.). The finding of this paper was in agreement with IPBES (2019). Further, WEPs are threatened by the unwillingness of the young generation to gain lore and cultural taboos. There are no conservation measures taken to conserve some life-saving WEPs in the study area (Table $6)$. The result of the present study was similar findings of 
Uprety et al. (2016) in Nepal. Hence, This study was the first attempt to explore the potential contribution of wild edible plants to sustainable food security in North Wollo, Ethiopia. It will be a baseline study and provide relevant information for policy-makers and managers about local peoples' perceptions for conservation and management of WEPs in north Wollo.

To conclude, malnutrition and food scarcity are still among the most striking challenges facing the humanitarian crisis. Similarly, million Ethiopians were chronically food insecure citizens. The study area is also among the food insecure areas in Ethiopia. The findings of this study showed that thousands of citizens were food insecure $(40.7 \%)$ in North Wollo. In context to this, WEPs are a warranty to sustainable household food security in the study area. However, the potential resources of WEPs are threatened with anthropogenic causes (deforestation for firewood, charcoal, construction materials, agricultural land demand, overexploitation, etc.). Hence, this study will be a baseline study and provide relevant information for policymakers and managers about local peoples' perceptions for conservation and management of WEPs sustainability and stability in food security in North Wollo.

\section{REFERENCES}

Addis G, Asfaw Z, Woldu Z. 2013. The role of wild and semi-wild edible plants in household food sovereignty in Hamer and Konso communities, South Ethiopia. Ethnobot Res Appl 11: 251-271.

Amarew. 2005. Extension plan Archived 2010-06-12 at the Wayback Machine.

Ashagre M, Asfaw Z, Kelbessa E. 2016.Ethnobotanical study of wild edible plants in Burji District, Segan Area Zone of Southern Nations, Nationalities and Peoples Region (SNNPR), Ethiopia. Journal of Ethnobiology and Ethnomedicine.12:32. DOI 10.1186/s13002-016-0103-1.

Assefa A, Abebe T. 2011. Wild edible trees and shrubs in the semi-arid lowlands of southern Ethiopia. J Sci Dev 1 (1): 5-19.

Awas T.1997. A Study on The Ecology and Ethnobotany of NonCultivated Food Plants and Wild Relatives of Cultivated Crops in Gambela Region, Southwestern Ethiopia [M. Sc. Thesis], Addis Ababa University, Addis Ababa, Ethiopia.

Balemie K, Kebebew F. 2006. Ethnobotanical study of wild edible plants in Derashe and Kucha Districts, South Ethiopia. J Ethnobiol Ethnomed 2 (1): 1-9. DOI: 10.1186/1746-4269-2-53

Barlow J, Gardner TA, Araujo IS, Ávila-Pires TC, Bonaldo AB, Costa JE Esposito MC, Ferreira LV, Hawes J, Hernandez MIM, et al.2007. Quantifying the biodiversity value of tropical primary, secondary, and plantation forests. Proc Natl Acad Sci USA 104 (47): 18555-18560. DOI: $10.1073 /$ pnas.0703333104

Berihun T, Molla E. 2017. Study on the diversity and use of wild edible plants in Bullen District, Northwest Ethiopia. J Bot. DOI: $10.1155 / 2017 / 8383468$.

Black RE, Victora CG, Walker SP, Bhutta ZA, Christian P, Onis MD, Ezzati M, Grantham-McGregor S, Katz J, Martorell R, UUauy R. 2013. Maternal and child undernutrition and overweight in lowincome and middle-income countries. Lancet 382 (9890): 427-451. DOI: 10.1016/S0140-6736 (13)60937-X.

Boedecker J, Termote C, Assogbadjo AE, Van Damme P, Lachat C. 2014 The dietary contribution of wild edible plants to women's diets in the buffer zone around the Lama Forest, Benin, and underutilized potential. Food Secur 6 (6): 833-849. DOI: 10.1007/s12571-0140396-7.

Bremner J. 2012. Population and Food Security: Africas Challenge, Population Bureau.

Burju T, Hundera K, Kelbessa E. 2013. Floristic composition and structural analysis of jibat humid Afromontane Forest, West Shewa
Zone, Ethiopia. Ethiop J Educ Sci 8 (2): 11-34. DOI: 10.4314/star.v2i2.98887.

CBD. 2009. Convention on Biological Diversity (CBD) Ethiopia's 4th Country Report. Institute of Biodiversity Conservation. Addis Ababa, Ethiopia.

Central Statistical Agency of Ethiopia (CSAE) and ICF International. 2016. Ethiopia Demographic and Health Survey. Addis Ababa, Ethiopia, and Rockville, Maryland, USA.

Central Statistical Agency of Ethiopia (CSAE). 2014. Ethiopian MiniDemographic and Health Survey. Addis Ababa, Ethiopia.

Chazdon RL. 2018. Protecting intact forests requires holistic approaches. Nat Ecol Evol 2 (6): 915-915. DOI: 10.1038/s41559-018-0546-y.

Christiaensen L, Alderman H. 2004. Child malnutrition in Ethiopia: can maternal knowledge augment the role of income?' Econ Dev Cult Change 52 (2): 287-312. DOI: 10.1086/380822.

Fentahun T, Hager H. 2008. Exploiting, a locally available resource for food and nutritional security enhancement: wild fruits diversity, potential, and state of exploitation in the Amhara region of Ethiopia. Food Secur 1 (2): 207-219. DOI: 10.1007/s12571-009-0017-z.

Gebretsadik T. 2016. Causes for biodiversity loss in Ethiopia: A review from conservation perspective. J Nat Sci Res 6 (11): 32-40.

Hailu S. 2013. The impact of disaster risk management interventions in humanitarian programmes on household food security. The Case of East Africa, Ethiopia, Amhara Region, North Wollo Zone. https://reliefweb.int.

Heywood VH. 2011. Ethnopharmacology, food production, nutrition, and biodiversity conservation: Towards a sustainable future for indigenous people. $\mathrm{J}$ Ethnopharmacol 137 (1): 1-15. DOI: 10.1016/j.jep.2011.05.027.

Hunter D, Ozkan I, Beltrame MOD, Samarasinghe WLG, Wasike VW, Charrondiere UR, Borelli T, Sokolow J. 2016. Enabled or disabled: is the environment right for using biodiversity to improve nutrition. 3: 14. DOI: $10.3389 /$ fnut. 2016.00014

International Society of Ethnobiology. 2006. International Society of Ethnobiology Code of Ethics (with 2008 additions). https:// ethnobiology net/code-of-ethics.

IPBES. 2019. Global assessment report on biodiversity and ecosystem services of the Intergovernmental Science-Policy Platform on Biodiversity and Ecosystem Services. In: Brondizio ES, Settele J, Díaz S, Ngo HT (eds) IPBES secretariat, Bonn, Germany.

Lulekal E, Asfaw Z, Kelbessa E, Damme PV. 2011. Wild edible plants in Ethiopia: a review on their potential to combat food insecurity. Afr Focus 24 (2): 71-121. DOI: 10.1163/2031356X-02402006

Mahapatra AK, Panda PC. 2012. Wild edible fruit diversity and its significance in the livelihood of indigenous tribal: evidence from eastern India. Food Secur 4 (2): 219-234. DOI: 10.1007/s12571-0120186-z.

Mengistu F, Hager H.2008. Wild edible fruit species cultural domain, informant species competence and preference in three Districts of Amhara Region, Ethiopia. Ethnobot Res Appl 6: 487-502. DOI: 10.17348/era.6.0.487-502.

Meseret D. 2016. Land degradation in Amhara Region of Ethiopia: Review on extent. Impacts Rehabil Practices 6 (1):120-130.

Mulatie M, Tsegaye S, Mulu G, Bayleyegn A, Assefa M. 2015. GIS and remote sensing-based forest resource assessment, quantification, and mapping in Amhara Region, Ethiopia. Landscape dynamics, soils, and hydrological processes in varied climates, Switzerland. DOI 10.1007/978-3-319-18787-7_2.

North Wollo Economic Development Plan and Strategies Office. 2019. General annual report of North Wollo, Amhara regional state, Ethiopia.

Petropoulos SA, Karkanis A, Martins N, Ferreira ICFR. 2018. Edible halophytes of the Mediterranean basin: Potential candidates for novel food products. Trends Food Sci Technol 74: 69-84. DOI: 10.1016/j.tifs.2018.02.006.

Pinela J, Carvalho AM, Ferreira IC. 2017. Wild edible plants: Nutritional and toxicological characteristics, retrieval strategies, and importance for today's society. Food Chem Toxicol 110: 165-188. DOI: 10.1016/j.fct.2017.10.020 .

Redzic J. 2006. Wild edible plants and their traditional use in human nutrition in Bosnia-Herzegovina. Ecol Food Nutr 45 (3): 189-232. DOI: $10.1080 / 03670240600648963$.

Regassa T, Kelbessa E, Asfaw Z. 2014. Ethnobotany of wild and semiwild edible plants of Chelia District, West-Central Ethiopia. Sci Technol Arts Res J 3 (4): 122-134. DOI: 10.4314/star.v3i4.18. 
Russo A, Escobedo FJ, Cirella GT, Zerbe S. 2017. Edible green infrastructure: An approach and review of provisioning ecosystem services and disservices in urban environments. Agric Ecosyst Environ 242: 53-66. DOI: 10.1016/j.agee.2017.03.026</web-URLs

Sales BD, Folkman S (eds). 2000. Ethics in research with human participants. American Psychological Association, Washington, DC.

Uprety Y, Poudel RC, Gurung J, Chettri N, Chaudhary RP. 2016. Traditional use and management of NTFPs in Kangchenjunga landscape: Implications for conservation and livelihoods. J Ethnobiol Ethnomed 12 (1): 1-59. DOI: 10.1186/s13002-016-0089-8.
WHO. 2013. World Health Organization, Essential Nutrition Actions: Improving Maternal, Newborn, Infant and Young Child Health and Nutrition, WHO Document Publications Services, Geneva, Switzerland.

Yazew T. 2020. Review on dietary contribution of wild edible food biodiversity to food security and micronutrient status of children in Ethiopia. J Health Environ Res 6 (1): 27-30. DOI: $10.11648 /$ j.jher.20200601.13 
Appendix 1. Semi-structured questions addressed to the interviewee and focus group discussions

Part I: General information of the respondents in the research area Name Village Code: EST

1. Sex 1. Male 2. Female

2. Age in Years 1. 15-30 2. 31-46 3. 47-62 4. 63-78 5. Above 78

3. Religion: 1. Orthodox 2. Muslim 3. Protestant 4. Catholic 5. Others

4. Education: 1. No eduction 2. Primary 3. Secondary 4. Higher

5. Occupation: 1. Farmer/Mixed 2. Civil worker 3. Private business/ Merchant 4. Not working

6. Family size $1.1-32 \cdot 4-73 \cdot 8-114$. Above 12

7. Foods secure 1. Yes 2. No

8. Familiarity with WEPs 1. Yes, 2. No 3. Little bit

9. From where do you collect wild edible plants most?

1. Forest 2. Shrubland 3. Grassland 4. Agricultural land

\section{Part II: Semi-structured interview on wild edible plants in the study area}

10. What is the most widely seen habit of the wild edible plants in your environment?

1. Tree 2. Shrubs 3. Herb 4. Climber

11. What is the dominant part of WEPs used in your village?

1. Fruit 2. Leaf 3. Root/tubers 4. Aerial shoot

12. In what way you consume WEPs in your village?

1. Raw state 2. Cooked 3. Roasted 4. Processed as alcoholic drink or juice

13. What is your first choice to use wild edible plants in your village?

1. Supplementary food 2. Medicine 3. Spice 4. Firewood 5. Charcoal 6. Timber production

7. Ecological purpose

14. In which season does wild edible plants are abundant and available most?

1. Summer 2. Winter 3. Autumn 4. Throughout the year

15. What is your approximate annual yield for the most commonly used WEPs in your village?

1. $0-25 \mathrm{~kg} 2.26-50 \mathrm{~kg} 3.51-75 \mathrm{~kg}$ 4. 76-100kg 5. $>100 \mathrm{~kg}$ (List and rank them)

16. The role of collecting and harvesting wild edible plants in your home is mostly by:

1. Children 2. Women 3. Men 4. All

17. What is the most significant threat to WEPs in your village?

1. Deforestation 2. Agricultural expansion 3. Overharvesting 4. Habitat destruction and loss 5. Others

18. What is your first challenge to domesticate and cultivate WEPs in your home garden?

1. Strong traditional beliefs 6 . Un pleasant taste

2. Religious taboos 7. The time it has taken for collection

3. Inadequate labor resources within the family 8 . Low volume and unsustainable harvest

4. Erosion of lore by the young generation

5. Inadequate profit in the market (If others, please specify)

19. What conservation measure do you use for WEPs?

1. In situ conservation 2. Seed bank 3. No conservation activities

\section{Part III: Interview for Focus group interviewees}

1. Did you use wild edible plants in your local area? If yes, how? If No, why?

2. List and rank the most popular wild edible plants? Which is abundant most? Why?

3. List and rank the wild edible plants you see in the market?

4. What is the significance of wild edible plants in your family?

5. Do you think wild edible plants have any side effects on your health (specify why and which species).

6. Do you think that we must conserve WEPs around our home or agricultural field? Why? 